\title{
Metabolism of sulfoacetate by environmental Aureobacterium sp. and Comamonas acidovorans isolates
}

\author{
Janice E. King† and John P. Quinn \\ Author for correspondence: John P. Quinn. Tel: +44 1232272 287/250. Fax: +44 1232236505. \\ e-mail: j.quinn@qub.ac.uk
}

School of Biology and Biochemistry, The Queen's University of Belfast, Medical Biology Centre, 97 Lisburn Road, Belfast BT9 7BL, UK

\begin{abstract}
Newly isolated environmental strains of Comamonas acidovorans and Aureobacterium sp. were found to mineralize sulfoacetate at concentrations up to at least $50 \mathrm{mM}$. Transient sulfite release was detected during growth on sulfoacetate, with essentially quantitative accumulation of sulfate. Cell-free conversion of sulfoacetate could not be obtained, but resting-cell studies indicated that cleavage of the $\mathrm{C}-\mathrm{S}$ bonds of both sulfoacetate and sulfoacetaldehyde was induced only when sulfoacetate was the sole carbon and energy source. A sulfite-oxidizing activity was also induced under these conditions. Sulfoacetaldehyde sulfo-lyase activity was demonstrated by in vitro assay and by gel zymography in extracts of cells grown on sulfoacetate as sole carbon source. This activity was not present in acetate-grown cells, or in cells grown on sulfoacetate as sole sulfur source. Results suggest that sulfoacetate mineralization in both isolates may proceed by a novel pathway which involves an initial reduction to sulfoacetaldehyde and subsequent cleavage of the C-S bond to yield sulfite and acetate. The proposed pathway may be of environmental significance in the mineralization of plant sulfolipid.
\end{abstract}

Keywords: sulfoacetate, sulfoacetaldehyde sulfo-lyase, sulfite oxidase, Aureobacterium, Comamonas acidovorans

\section{INTRODUCTION}

Sulfonates are organic compounds of both biogenic and synthetic origin which contain the $\mathrm{R}-\mathrm{CH}_{n}-\mathrm{SO}_{3} \mathrm{H}$ moiety. They are widely distributed in the biosphere (Seitz \& Leadbetter, 1995); examples of commercially produced sulfonates include the aminobenzenesulfonates and their derivatives, which are used in the manufacture of dyes and optical brighteners, the detergent additive toluenesulfonate, and the linear alkyl surfactants. Naturally occurring sulfonates include taurine and isethionate (both found in mammalian tissues), methanesulfonate (an atmospheric oxidation product of gaseous dimethyl sulfide derived from marine organic matter), and the plant sulfolipid 1,2-diacyl-3-(6-sulfo-D-quinopyrosyl)-Lglycerol. An indication of their abundance, and of the relative recalcitrance conferred by the presence of the $\mathrm{C}-\mathrm{S}$ bond, is given by the estimate that synthetic sulfonates comprise about $10 \%$ of the organic loading of the river Rhine (Lee \& Clark, 1993), and that between 20 and $40 \%$ of total sulfur in terrestrial soils and marine

\footnotetext{
† Present address: Randox Laboratories Ltd, Crumlin BT29 4QY, UK.
}

sediments accumulates in the $\mathrm{C}-\mathrm{S}$ linkage of naturally occurring sulfonates, which are almost exclusively aliphatic (Vairavamurthy et al., 1994).

Research on the biodegradation of sulfonates has concentrated largely on those of anthropogenic origin and there is comparatively little information on the microbial metabolism of biogenic compounds containing the C-S bond (Uria-Nickelsen et al., 1993). It has been demonstrated, however, that taurine may be mineralized by a small number of environmental bacteria via the desulfonation of sulfoacetaldehyde by the enzyme sulfoacetaldehyde sulfo-lyase (Kondo \& Ishimoto, 1972, 1975; Shimamoto \& Berk, 1980); the products are sulfite and acetate. In addition, the mineralization of isethionate, also via sulfoacetaldehyde, by an environmental Acinetobacter isolate has recently been demonstrated in this laboratory (King et al., 1997). In general, however, the ability to utilize only the sulfonate moiety of sulfonates appears to be very widespread amongst bacteria (Seitz et al., 1993; Seitz \& Leadbetter, 1995; King \& Quinn, 1997) and may be controlled as part of the sulfate-starvation-induced stimulon (Kertesz, 1996). 
A particularly striking gap exists in our knowledge of the mineralization of sulfoquinovose (6-sulfo-6-deoxyglucose). This is clearly a major component in the biogeochemical sulfur cycle, since it is the sulfonated moiety of plant sulfolipid and the product of sulfolipid catabolism by an endogenous acyl hydrolase in senescent leaf tissue (Harwood \& Nicholls, 1979). An early report (Martelli \& Benson, 1964) indicated that the metabolism of radiolabelled sulfoquinovose by a Flavobacterium sp. did not involve its prior desulfonation but most probably involved a 'sulfoglycolytic' pathway, and that sulfoacetate was an intermediate. Evidence for the subsequent formation of acetate, possibly through hydrolytic cleavage of sulfoacetate, was also presented. A later study (Martelli \& Souza, 1969) indicated that glycolate and sulfate were products of an oxidative cleavage of the C-S bond of sulfoacetate in extracts of a Pseudomonas aeruginosa isolate that used the compound as sole carbon, energy and sulfur source.

We now describe the utilization of sulfoacetate as sole carbon and energy source by newly isolated Grampositive and Gram-negative environmental bacterial strains, and report in vivo and in vitro investigations of the degradative pathway involved.

\section{METHODS}

Isolation and growth of sulfoacetate-degrading bacteria. Isolates SFCD1 and SFCD2 were obtained in the course of a study of sulfonate utilization by environmental microorganisms (King \& Quinn, 1997) on the basis of their ability to use sulfoacetate as a carbon and energy source. Both originated in Laundromat Pond (near Summit Lake, north-central Wisconsin, USA), a stagnant water body containing decaying vegetable matter into which the wastewater from a small laundromat discharges (Jimenez et al., 1991). The Gramnegative isolate SFCD1 has been subsequently identified at the National Collections of Industrial and Marine Bacteria (Aberdeen, UK) as most closely resembling Comamonas acidovorans, although it was atypical in its inability to utilize fructose and in its failure to produce alkali from DL-tartrate. The Gram-positive isolate SFCD2 was identified following fatty acid profiling at the National Collection of Plantpathogenic Bacteria (Harpenden, UK) as a probable Aureobacterium or Curtobacterium species; its profile closely matched that of Aureobacterium saperdae. It was identified as Curtobacterium sp. by the Biolog GP Microplate Identification System.

The isolates were grown on a basal culture medium containing [(l tap water $\left.)^{-1}\right]: \mathrm{NH}_{4} \mathrm{Cl}, 1: 0 \mathrm{~g} ; \mathrm{KCl}, 0 \cdot 2 \mathrm{~g} ; \mathrm{MgSO}_{4} .7 \mathrm{H}_{2} \mathrm{O}$, $0.2 \mathrm{~g} ; \mathrm{CaCl}_{2} \cdot 2 \mathrm{H}_{2} \mathrm{O}, 0.001 \mathrm{~g} ;$ ferric ammonium citrate, $0.001 \mathrm{~g}$; yeast extract, $0.05 \mathrm{~g} ; 5 \mathrm{mM}$ phosphate buffer $(\mathrm{pH} 7.2)$; trace elements solution (Krieg, 1981), $1 \mathrm{ml}$; and vitamin solution (Difco), $1 \mathrm{ml}$. Sulfoacetate $(20 \mathrm{mM})$ routinely served as carbon and energy source, and the medium was filtersterilized. Flasks $(0.5 \mathrm{l})$ containing $60 \mathrm{ml}$ inoculated medium were incubated at $27^{\circ} \mathrm{C}$ on a rotary shaker at 100 r.p.m. Bulk cultures were similarly grown in a 6.51 fermenter. Sulfate-free medium was prepared when required by the replacement of magnesium sulfate by magnesium chloride, and by the use of deionized distilled water rather than tap water. Sulfur-starved cells were produced by growth in sulfate-free medium containing $100 \mathrm{mM}$ acetate as carbon source and sup- plemented with $0.08 \mathrm{mM}$ sodium sulfate as sole sulfur source. They were harvested in stationary phase, $24 \mathrm{~h}$ after evidence of sulfur starvation was first obtained (i.e. when a gradual decrease in growth rate was observed when compared to growth in a control flask containing $0.5 \mathrm{mM}$ sulfate). Sulfur limitation was confirmed by the fact that aliquots removed from the culture increased in optical density only in response to sulfate supplementation; final cell yield was proportional to the level of sulfate addition.

Carbon-starved cells were produced by growth in medium containing $50 \mathrm{mM}$ sodium acetate as sole carbon and energy source and in which all other components were supplied at twice the normal concentration. They were harvested $2 \mathrm{~h}$ after evidence of the onset of carbon starvation had been confirmed (as for sulfur-limited cells).

Growth of cultures was followed by measuring the $\mathrm{OD}_{650}$ (PU $8200 \mathrm{UV} /$ vis spectrophotometer; Pye-Unicam) and culture supernatants were assayed for sulfate (Sorbo, 1987) and sulfite (Johnston et al., 1975). All growth experiments reported were carried out on at least three separate occasions; typical results are shown.

Chemicals. All chemicals, unless otherwise stated, were obtained from Sigma/Aldrich and were of the highest purity available. Sulfoacetate (disodium salt) was obtained from Kodak Laboratory and Research Chemicals and hydroxymethylsulfonate was a gift from Dr L. E. Hallas (Monsanto Co., St Louis, MO, USA). Sulfoacetaldehyde was synthesized as the bisulfite addition complex by QUCHEM, the Custom Synthesis and Process Development Research Centre, School of Chemistry, The Queen's University of Belfast, UK, using the method of Kondo et al. (1971). Sulfoacetaldehyde was prepared from the bisulfite adduct as described by White (1988). A fresh sample was prepared daily.

In vitro enzyme assays. Cells were harvested in midexponential phase by centrifugation at $10000 \mathrm{~g}$ for $15 \mathrm{~min}$ at $4{ }^{\circ} \mathrm{C}$. After washing twice in $50 \mathrm{mM}$ phosphate buffer ( $\mathrm{pH} 7 \cdot 2$ ), the cell pellet was resuspended to a concentration of $0.3 \mathrm{~g}$ cells ml $^{-1}$ in buffer containing $0.01 \%$ DTT. Cells were disrupted ultrasonically using a Soniprep 150 ultrasonic disintegrator (MSE) on an ice/water mixture at $16 \mathrm{kHz}$ for $5 \mathrm{~min}$ ( $30 \mathrm{~s}$ sonication followed by $2 \mathrm{~min}$ cooling). The resulting homogenate was centrifuged at $25000 \mathrm{~g}$ for $30 \mathrm{~min}$ at $4{ }^{\circ} \mathrm{C}$ and the supernatant was retained as the crude cell-free extract. Protein concentrations were measured by the method of Bradford (1976). The extract was stored on ice and used for enzyme assays on the same day.

$\mathrm{C}-\mathrm{S}$ bond cleavage activity was assayed at $30^{\circ} \mathrm{C}$ in triplicate reaction mixtures containing cell extract $\left(5 \mathrm{mg}\right.$ protein $\left.\mathrm{ml}^{-1}\right)$, $5 \mathrm{mM}$ sulfoacetate or sulfoacetaldehyde, $0.01 \%$ DTT, $50 \mathrm{mM}$ phosphate buffer ( $\mathrm{pH} 7 \cdot 2$ ) and distilled water to a total volume of $6 \mathrm{ml}$. The reaction was initiated by the addition of the cell extract and terminated (in samples removed at timed intervals) by addition of $0.1 \mathrm{ml} 50 \%(\mathrm{w} / \mathrm{v})$ trichloroacetic acid. After centrifugation, supernatants were analysed for sulfate (Sorbo, 1987) and for acetate using an enzyme-based Acetate Test kit (Boehringer Mannheim) with a lower detection limit of $10 \mu \mathrm{g} \mathrm{ml}^{-1}$. Sulfite-oxidizing activity (EC 1.8.3.1) in cell extracts was assayed similarly, with freshly prepared sodium sulfite $(10 \mathrm{mM})$ as substrate in the presence of $0.02 \%$ DTT; reaction supernatants were assayed for sulfate. Cytochrome$c$-reducing activity was determined in assays $(3.0 \mathrm{ml}$ reaction volume) containing: $50 \mathrm{mM}$ Tris $/ \mathrm{HCl}$ buffer $(\mathrm{pH} 8.0$ ), $0.15 \mathrm{mM}$ cytochrome $c$ (horse heart), $2 \mathrm{mM}$ freshly prepared sodium sulfite and $6 \mathrm{mg}$ cell-extract protein. Reactions were started by the addition of sulfite and the $A_{550}$ was recorded 
over $5 \mathrm{~min}$. Arylsulfatase (EC 3.1.6.1) was assayed in $1.0 \mathrm{ml}$ reaction volumes containing 4-nitrocatechol sulfate $(10 \mathrm{mM})$, $100 \mathrm{mM}$ Tris/acetate buffer $(\mathrm{pH} \mathrm{9.0)}$ and cell extract $(4 \mathrm{mg}$ protein $\mathrm{ml}^{-1}$ ); production of 4-nitrocatechol was measured at $515 \mathrm{~nm}$ (extinction coefficient $=13 \mathrm{mM}^{-1}$ ) (Kertesz et al., 1993).

Resting-cell assays. Cells were harvested by centrifugation and resuspended to a concentration of $200 \mathrm{mg}$ fresh weight $\mathrm{ml}^{-1}$ in $50 \mathrm{mM}$ phosphate buffer ( $\mathrm{pH} 7 \cdot 2$ ). Assays contained $10 \mathrm{mM}$ sulfoacetate, sulfoacetaldehyde or sodium sulfite, $20 \mathrm{mg}$ whole cells $\mathrm{ml}^{-1}, 50 \mathrm{mM}$ phosphate buffer ( $\mathrm{pH} 7 \cdot 2$ ), $0.02 \%$ DTT (when sulfite was the substrate) and distilled water to a total volume of $7 \mathrm{ml}$. Assay mixtures were preincubated at $30^{\circ} \mathrm{C}$ and reactions were started by the addition of substrate; $1 \mathrm{ml}$ aliquots were removed hourly and the reactions were stopped by centrifugation prior to assay of the supernatants for sulfate. Control assays, from which either substrate or cell suspension had been omitted, were carried out in parallel. All substrates were stable under the assay conditions used and all assays were carried out in triplicate.

Gel zymography. Sulfoacetaldehyde sulfo-lyase (EC 4.4.1.12) activity was demonstrated using a modification of the method of Kondo \& Ishimoto (1975). Aliquots (12.5 $\mu \mathrm{l})$ of crude extract $\left(5 \mathrm{mg}\right.$ protein $\mathrm{ml}^{-1}$ ), obtained from cells of $C$. acidovorans SFCD1 and Aureobacterium sp. SFCD2 grown on sulfoacetate as carbon and energy source, were mixed with equal volumes of sample buffer and loaded into wells of duplicate precast $8-16 \%$ Tris/glycine gels (Novex). Highmolecular-mass markers (Pharmacia Biotech) were also run. Following electrophoresis ( $125 \mathrm{~V}$ for $3 \mathrm{~h}$ ), one gel was stained with Coomassie blue according to the manufacturer's instructions; the duplicate gel was stained to detect sulfoacetaldehyde sulfo-lyase activity by bathing it in darkness for $1 \mathrm{~h}$ at $30^{\circ} \mathrm{C}$ in an assay mixture $(100 \mathrm{ml})$ containing $10 \mathrm{mM}$ sulfoacetaldehyde, $2 \mathrm{mM} \mathrm{MgCl}{ }_{2}, 50 \mathrm{mM}$ phosphate buffer $(\mathrm{pH} 7 \cdot 2)$ and $0 \cdot 1 \mathrm{mM}$ thiamin pyrophosphate (Kondo \& Ishimoto, 1975). The gel was then rinsed twice with distilled water, immersed in a $0.03 \%(\mathrm{w} / \mathrm{v})$ solution of malachite green and incubated as above for $2 \mathrm{~h}$. It was photographed immediately after staining.

\section{RESULTS}

\section{Growth of isolates}

The growth of C. acidovorans SFCD1 and Aureobacterium sp. SFCD2 on $20 \mathrm{mM}$ sulfoacetate as the source of carbon and energy, and the transient release of sulfite and accumulation of sulfate in the culture supernatants, are shown in Fig. 1. In an uninoculated control experiment, no sulfate accumulated from $20 \mathrm{mM}$ sulfoacetate over the incubation period. The cell yield for Aureobacterium sp. SFCD2 was linear up to at least $50 \mathrm{mM}$ sulfoacetate (Fig. 2).

Besides sulfoacetate, both strains also grew on $10 \mathrm{mM}$ isethionate as sole carbon and energy source. $C$. acidovorans SFCD1, but not Aureobacterium sp. SFCD2, grew on $10 \mathrm{mM}$ taurine as a carbon, energy and nitrogen source. The following sulfonates (all at $10 \mathrm{mM}$ ) failed to support growth of either isolate as carbon and energy sources: sulfoacetaldehyde, methanesulfonate, ethanesulfonate, hydroxymethylsulfonate, sulfosuccinate, benzenesulfonate, naphthalene-1-sulfonate, sulfanilic acid and $p$-toluenesulfonate.

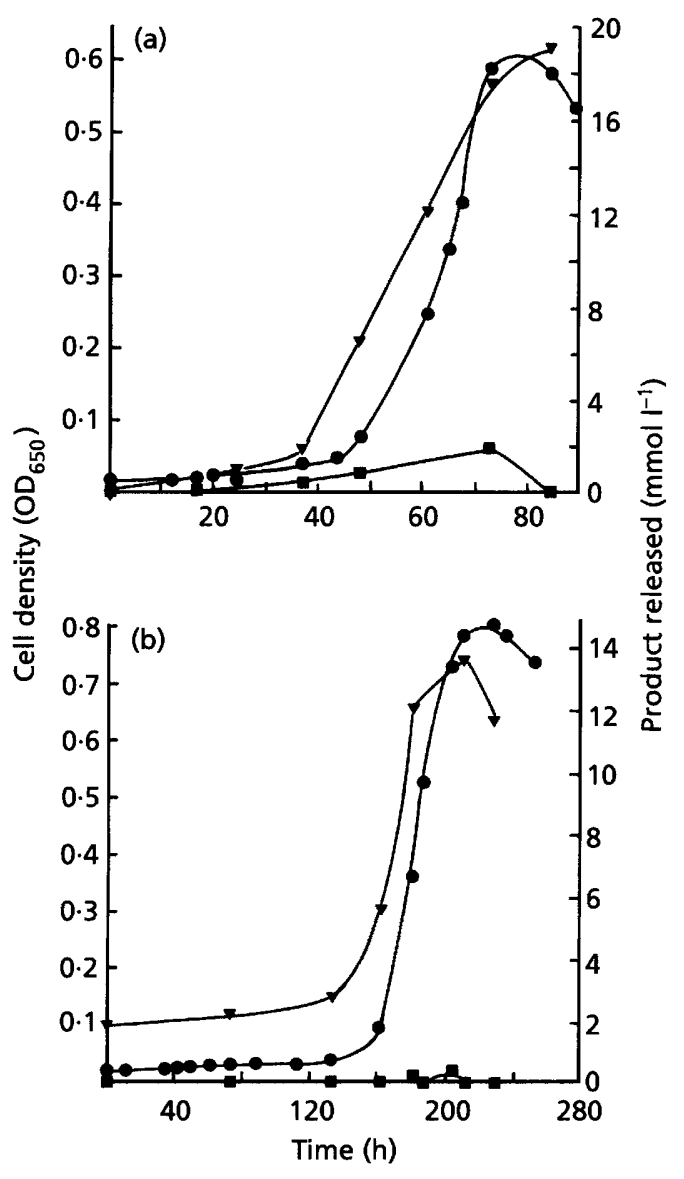

Fig. 1. Growth of (a) C. acidovorans SFCD1 and (b) Aureobacterium sp. SFCD2 on sulfoacetate $(20 \mathrm{mM})$ as the source of carbon and energy. O. Optical density; $\nabla$, sulfate concentration in the growth medium; $\boldsymbol{\square}$, sulfite concentration in the growth medium.

\section{In vitro enzyme activity}

To examine $\mathrm{C}-\mathrm{S}$ bond cleavage in sulfoacetate in greater detail, attempts were made to obtain cell-free activity in extracts of sulfoacetate-grown cells. Despite a variety of additions in various combinations and concentrations (NADH, NADPH, FMN, FAD, CoA, phenazine methosulfate, $\mathrm{K}^{+}, \mathrm{Mg}^{2+}$ or yeast extract), in vitro cleavage of the $\mathrm{C}-\mathrm{S}$ bond of sulfoacetate was not observed in extracts of either isolate, nor was activity detected in cells permeabilized by a range of standard protocols.

Both extracts were, however, found to contain sulfoacetaldehyde sulfo-lyase activity; Fig. 3 shows the release of sulfate and acetate from sulfoacetaldehyde by extracts of sulfoacetate-grown cells of Aureobacterium sp. SFCD2. Both extracts also contained a sulfite oxidase activity which was shown, in Aureobacterium sp. SFCD2, to have $\mathrm{pH}$ and temperature optima of $7 \cdot 0$ and $37^{\circ} \mathrm{C}$, respectively; rates of up to $2 \mu \mathrm{mol}$ sulfate formed $\mathrm{h}^{-1}$ (mg cell-extract protein) ${ }^{-1}$ were typically obtained (results not shown). Extracts of sulfoacetate-grown cells caused the reduction of cytochrome $c$ on addition of sulfite; no cytochrome $c$ reduction was observed in 


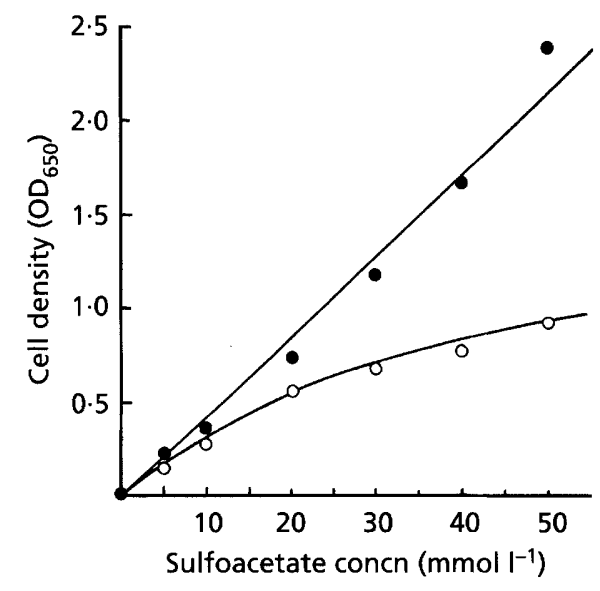

Fig. 2. Cell yields of $C$. acidovorans SFCD1 (O) and Aureobacterium sp. SFCD2 (O) following growth in medium containing various concentrations of sulfoacetate as carbon and energy source.

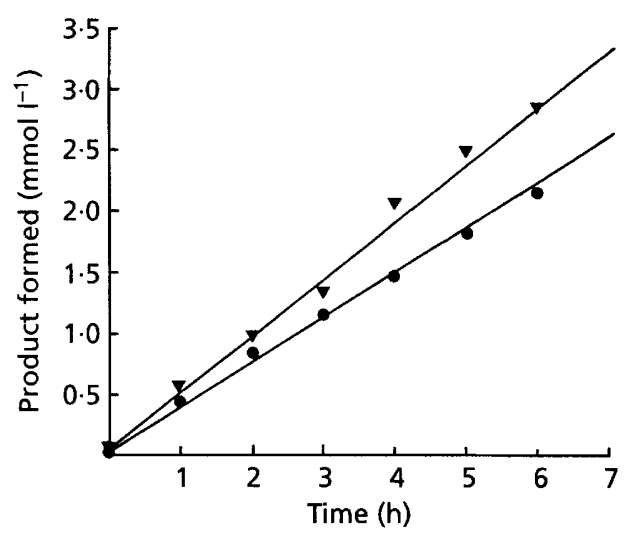

Fig. 3. Release of sulfate $(\boldsymbol{\nabla})$ and acetate (O) from sulfoacetaldehyde by extracts of sulfoacetate-grown cells of Aureobacterium sp. SFCD2.

control assays lacking sulfite, or cell extract, or containing extract from acetate-grown cells.

\section{Demonstration of sulfoacetaldehyde sulfo-lyase activity by gel zymography}

When gels containing extracts from cells of C. acidovorans SFCD1 and Aureobacterium sp. SFCD2 grown on sulfoacetate as carbon and energy source were stained for sulfoacetaldehyde sulfo-lyase activity, two discrete bands were observed (results not shown) due to the formation of an addition product of sulfite (released from sulfoacetaldehyde by the action of the sulfo-lyase) and the dye (Kondo \& Ishimoto, 1975). Sulfo-lyase activity in extracts of $C$. acidovorans SFCD1 corresponded to a major protein band at an apparent molecular mass of about $220 \mathrm{kDa}$; that for Aureobacterium sp. SFCD2 corresponded to a molecular mass
Table 1. Induction of C-S bond cleavage and sulfiteoxidizing activities in resting cells of Aureobacterium sp. SFCD2 pregrown on acetate

Cells were pregrown to mid-exponential phase on $50 \mathrm{mM}$ acetate, washed, and resuspended for $9 \mathrm{~h}$ in a basal salts 'induction' medium containing either $10 \mathrm{mM}$ sulfoacetate or sulfoacetaldehyde, or for $4 \mathrm{~h}$ in medium containing $10 \mathrm{mM}$ sodium sulfite. Cells were subsequently assayed for their ability to release sulfate from sulfoacetate, sulfoacetaldehyde or sulfite (each supplied at $10 \mathrm{mM}$ ).

\begin{tabular}{|llc|}
\hline Potential inducer & Assay substrate & Activity* \\
\hline \multirow{2}{*}{ None } & Sulfoacetate & $0 \cdot 0$ \\
& Sulfoacetaldehyde & $0 \cdot 0$ \\
& Sulfite & $0 \cdot 0$ \\
Sulfoacetate & Sulfoacetate & $43 \cdot 0 \pm 5 \cdot 3$ \\
& Sulfoacetaldehyde & $19 \cdot 3 \pm 0 \cdot 7$ \\
Sulfoacetaldehyde & Sulfite & $18 \cdot 7 \pm 0 \cdot 9$ \\
& Sulfoacetate & $0 \cdot 0$ \\
Sulfite & Sulfoacetaldehyde & $0 \cdot 0$ \\
& Sulfite & $0 \cdot 0$ \\
& Sulfoacetate & $0 \cdot 0$ \\
& Sulfoacetaldehyde & $0 \cdot 0$ \\
& Sulfite & $100 \cdot 0 \pm 14 \cdot 4$ \\
\hline
\end{tabular}

* Activity is expressed as nmol sulfate produced $\mathrm{h}^{-1}(\mathrm{mg} \text { cells })^{-1}$; each value is the mean of triplicate assays \pm SEM.

of about $330 \mathrm{kDa}$. A control extract of taurine-grown cells of an environmental Burkbolderia cepacia isolate obtained by enrichment was shown to contain sulfoacetaldehyde sulfo-lyase activity in a protein band with an apparent molecular mass of $220 \mathrm{kDa}$; the role of sulfoacetaldehyde sulfo-lyase in the mineralization of taurine is well-established (Kondo et al., 1971; Shimamoto \& Berk, 1980).

\section{Regulation of enzyme activities in Aureobacterium sp. SFCD2}

Further investigation of the regulation of $\mathrm{C}-\mathrm{S}$ bond cleavage activity was carried out in resting-cell suspensions of Aureobacterium sp. SFCD2. Cleavage of the $\mathrm{C}-\mathrm{S}$ bond of both sulfoacetate and sulfoacetaldehyde was inducible in the presence of sulfoacetate; such cells also contained inducible sulfite-oxidizing activity (Table 1). None of these activities was present in cells similarly exposed to sulfoacetaldehyde, or in acetate-grown cells. Cells exposed to sulfite contained only sulfite-oxidizing activity.

The presence of the enzymes sulfoacetaldehyde sulfolyase, sulfite oxidase and arylsulfatase was subsequently investigated in extracts of Aureobacterium sp. SFCD2 following growth in media lacking either a carbon or a sulfur source, or after harvest during mid-exponential phase in media in which sulfoacetate served as sole carbon and energy source, sole sulfur source, or sole carbon, energy and sulfur source. Rigorous precautions 
Table 2. Sulfoacetaldehyde sulfo-lyase, sulfite oxidase and arylsulfatase activities in cell extracts of Aureobacterium sp. SFCD2 grown under various conditions

\begin{tabular}{|lccc|}
\hline $\begin{array}{l}\text { Conditions for growth of } \\
\text { Aureobacterium sp. SFCD2 }\end{array}$ & $\begin{array}{c}\text { Sulfoacetaldehyde } \\
\text { sulfo-lyase* }\end{array}$ & $\begin{array}{c}\text { Sulfite } \\
\text { oxidase } \dagger\end{array}$ & Arylsulfatase $\dagger$ \\
\hline Sulfoacetate as carbon source & $9 \cdot 7 \pm 0 \cdot 7$ & $10 \cdot 0 \pm 0 \cdot 4$ & $0 \cdot 0$ \\
Sulfoacetate as sulfur source & $0 \cdot 0$ & $0 \cdot 0$ & $0 \cdot 0$ \\
Sulfoacetate as carbon and & $9 \cdot 0 \pm 0 \cdot 2$ & $9 \cdot 0 \pm 0 \cdot 2$ & $0 \cdot 0$ \\
$\quad$ sulfur source & $0 \cdot 0$ & $0 \cdot 0$ & $0 \cdot 0$ \\
Carbon-starved & $0 \cdot 0$ & $0 \cdot 0$ & $0 \cdot 4 \pm 0 \cdot 1$ \\
Sulfur-starved & & 0 \\
\hline
\end{tabular}

*Activity is expressed as nmol acetate produced $\min ^{-1}$ (mg cell-extract protein $)^{-1} \pm$ SEM.

† Activity is expressed as nmol sulfate produced $\mathrm{min}^{-1}$ (mg cell-extract protein $)^{-1} \pm$ SEM.

ensured the exclusion of all exogenous sources of sulfur, and control experiments confirmed that the stated limitations were operative. Sulfoacetaldehyde sulfolyase and sulfite oxidase activities were found only in extracts of cells grown on sulfoacetate as sole carbon and energy source or sole carbon, energy and sulfur source (Table 2). Activity of arylsulfatase, regarded as indicative of sulfate limitation in a number of bacterial species (Kertesz et al., 1993), was detected only under sulfur-starved conditions.

In a parallel experiment, sulfoacetaldehyde sulfo-lyase was assayed in cells of two soil Pseudomonas spp. isolated by us on the basis of their ability to metabolize taurine (results not shown). Activity of the enzyme was detected in cells grown on taurine as sole carbon and energy source, but not in cells grown on sulfoacetaldehyde as sole sulfur source.

\section{DISCUSSION}

This report provides substantial evidence to suggest that sulfoacetate mineralization in both the Gram-negative C. acidovorans SFCD1 and the Gram-positive Aureobacterium sp. SFCD2 involves an initial reduction of the molecule to sulfoacetaldehyde. Cleavage of the C-S bond by an inducible sulfoacetaldehyde sulfo-lyase follows, to produce sulfite and acetate; the sulfite is then oxidized to sulfate by an inducible oxidase. This degradative sequence is distinct from the only other reported route of microbial sulfoacetate metabolism, in which a direct oxidative cleavage of the sulfoacetate C-S bond by $P$. aeruginosa yielded glycolate and sulfate (Martelli \& Souza, 1969). The fact that broadly similar rates of sulfate accumulation from sulfoacetate, sulfoacetaldehyde and sulfite were observed in resting-cell suspensions of Aureobacterium sp. SFCD2 preadapted to sulfoacetate (Table 1) appears to confirm the physiological significance of the proposed sulfo-lyase pathway in sulfoacetate catabolism, though clearly a study of mutant strains lacking the sulfo-lyase would be required to provide definitive proof.

The involvement of sulfoacetaldehyde sulfo-lyase in the microbial metabolism of the major biogenic sulfonates taurine and isethionate has been demonstrated (Kondo et al., 1971, 1977; Shimamoto \& Berk, 1979, 1980; King et al., 1997), whilst sulfoacetate has been implicated (Martelli \& Benson, 1964) as an intermediate in the biodegradation of plant sulfolipid, the annual global production of which is estimated to be at least $3.6 \times 10^{13} \mathrm{~kg}$ (Harwood \& Nicholls, 1979). Sulfoacetaldehyde sulfo-lyase, a little-studied enzyme, may therefore play a major role in global biogeochemical cycling through its role in the mineralization of biogenic sulfonate-sulfur.

The mode of regulation of sulfoacetaldehyde sulfo-lyase in Aureobacterium sp. SFCD2 remains unclear. Its expression is not induced by its substrate, or by carbon or sulfur starvation, and appears to require the presence of sulfoacetate as a source of carbon (Table 2); however, it may also be subject to catabolite repression since its activity is not detected in cells grown on sulfoacetate as sole sulfur source in the presence of acetate as a source of carbon. The failure of sulfoacetaldehyde itself to induce the sulfo-lyase is not due to toxicity, since sulfoacetate-grown cells readily metabolized sulfoacetaldehyde at a concentration of $10 \mathrm{mM}$ (Table 1). These findings are, however, consistent with the report that isethionate, rather than sulfoacetaldehyde, induced sulfoacetaldehyde sulfo-lyase activity in cells of Acinetobacter sp. (King et al., 1997), and our finding that taurine, rather than sulfoacetaldehyde, induced the enzyme in two soil pseudomonads. The latter observation confirms an earlier report (with supporting genetic evidence) on the regulation of taurine catabolism in $P$. aeruginosa (Shimamoto \& Berk, 1980). Furthermore, these findings are consistent with our failure (King \& Quinn, 1997) over a prolonged period of elective culture, to isolate any environmental bacterial strain able to mineralize sulfoacetaldehyde, despite the fact that 97 out of 100 isolates could use the compound as sole sulfur source.

The results presented here add weight to recent evidence that different catabolic routes may operate when sulfonates are utilized by bacteria as carbon and energy sources, as opposed to sulfur sources, and that these pathways are thus independently regulated by the supply 
of carbon and sulfur to the cell (Kertesz et al., 1994; Seitz \& Leadbetter, 1995; Kertesz, 1996; King \& Quinn, 1997).

\section{ACKNOWLEDGEMENTS}

Janice E. King received a postgraduate studentship from the Department of Education for Northern Ireland.

\section{REFERENCES}

Bradford, M. M. (1976). A rapid and sensitive method for the quantitation of microgram quantities of protein utilizing the principle of protein-dye binding. Anal Biochem 72, 248-254.

Harwood, J. L. \& Nicholls, R. G. (1979). The plant sulpholipid - a major component of the sulphur cycle. Biochem Soc Trans 7 , $440-447$.

Jimenez, L., Breen, A., Thomas, N., Federle, T. W. \& Sayler, G. S. (1991). Mineralization of linear alkylbenzene sulfonate by a fourmember aerobic bacterial consortium. Appl Environ Mictobiol 57, 1566-1569.

Johnston, J. B., Murray, K. \& Cain, R. B. (1975). Microbial metabolism of aryl sulfonates. A re-assessment of colorimetric methods for the determination of sulphite and their use in measuring desulphonation of aryl and alkylbenzene sulphonates. Antonie leeuwenhoek 41, 493-511.

Kertesz, M. A. (1996). Desulfonation of aromatic sulfonates by Pseudomonas aertuginosa PAO. FEMS Microbiol Lett 137, 221-225.

Kertesz, M. A., Leisinger, T. \& Cook, A. M. (1993). Proteins induced by sulfate limitation in Escherichia coli, Pseudomonas putida, and Staphylococcus aureus. J Bacteriol 175, 1187-1190.

Kertesz, M. A., Cook, A. M. \& Leisinger, T. (1994). Microbial metabolism of sulfur- and phosphorus-containing xenobiotics. FEMS Microbiol Rev 15, 195-215.

King, J. E. \& Quinn, J.P. (1997). The utilization of organosulfonates by soil and freshwater bacteria. Lett Appl Microbiol 24, 69-73.

King, J. E., Jaouhari, R. \& Quinn, J.P. (1997). The role of sulfoacetaldehyde sulfo-lyase in the mineralization of isethionate by an environmental Acinetobacter isolate. Microbiology 143, 23.39-2.34.3.

Kondo, H. \& Ishimoto, M. (1972). Enzymatic formation of sulfite and acetate from sulfoacetaldehyde, a degradation product of taurine. J Biochem 72, 487-489.

Kondo, H. \& Ishimoto, M. (1975). Purification and properties of sulfoacetaldehyde sulfo-lyase, a thiamine pyrophosphate-dependent enzyme forming sulfite and acetate. J Biochem 78, 317-325.
Kondo, H., Anada, H., Ohsawa, K. \& Ishimoto, M. (1971). Formation of sulfoacetaldehyde from taurine in bacterial extracts. J Biochem 69, 621-623.

Kondo, H., Niki, H., Takahashi, S. \& Ishimoto, M. (1977). Enzymatic oxidation of isethionate to sulfoacetaldehyde in bacterial extract. J Biochem 81, 1911-1916.

Krieg, N. R. (1981). Enrichment and isolation. In Manual of Methods for General Bacteriology, pp. 112-142. Edited by P. Gerhardt, R. G. E. Murray, R. N. Costilow, E. W. Nester, N. A. Wood, N. R. Krieg \& G. B. Phillips. Washington, DC: American Society for Microbiology.

Lee, N. A. \& Clark, D. P. (1993). A natural isolate of Pseudomonas maltophilia which degrades aromatic sulfonic acids. FEMS Microbiol Lett 107, 151-156.

Martelli, H. L. \& Benson, A. A. (1964). Sulfocarbohydrate metabolism. 1. Bacterial production and utilization of sulfoacetate. Biochim Biophys Acta 93, 169-171.

Martelli, H. L. \& Souza, S. M. (1969). Biochemistry of sulfonic compounds. III. Formation of a two-carbon compound during the oxidation of sulfoacetate by a Pseudomonas strain. Biochim Biophys Acta 208, 110-115.

Seitz, A. P. \& Leadbetter, E. R. (1995). Microbial assimilation and dissimilation of sulfonate-sulfur. In Geochemical Transformations of Sedimentary Sulfur, pp. 365-376. Edited by M. A. Vairavamurthy \& M. A. Schoonen. Washington, DC: American Chemical Society.

Seitz, A. P., Leadbetter, E. R. \& Godchaux, W., III (1993). Utilization of sulfonates as sole sulfur source by soil bacteria including Comamonas acidovorans. Arch Microbiol 159, 440-444.

Shimamoto, G. \& Berk, R. S. (1979). Catabolism of taurine in Pseudomonas aeruginosa. Biochim Biophys Acta 569, 287-292.

Shimamoto, G. \& Berk, R. S. (1980). Taurine catabolism. II. Biochemical and genetic evidence for sulfoacetaldehyde sulfolyase involvement. Biochim Biophys Acta 632, 121-130.

Sorbo, B. (1987). Sulfate: turbidimetric and nephelometric methods. Methods Enzymol 143, 3-6.

Uria-Nickelsen, M. R., Leadbetter, E. R. \& Godchaux, W., III (1993). Sulphonate utilization by enteric bacteria. J Gen Microbiol 139 , 20.3-208.

Vairavamurthy, A., Zhou, W., Eglinton, T. \& Manowitz, B. (1994). Sulfonates: a novel class of organic sulfur compounds in marine sediments. Geochim Cosmochim Acta 58, 4681-4687.

White, R. H. (1988). Characterization of the enzymatic conversion of sulfoacetaldehyde and $\mathrm{L}$-cysteine into coenzyme $\mathrm{M}$ (2-mercaptothanesulfonic acid). Biochemistry 27, 7458-7462.

Received 6 May 1997; revised 5 August 1997; accepted 29 August 1997. 